\title{
Mesopelagic protists: diversity and succession in a coastal Arctic ecosystem
}

\author{
Ramon Terrado $^{1, *}$, Warwick F. Vincent ${ }^{2}$, Connie Lovejoy ${ }^{1}$ \\ ${ }^{1}$ Département de biologie, Québec-Ocean, and Institut de biologie intégrative et des systèmes (IBIS), Université Laval, \\ Québec City, Québec G1V 0A6, Canada \\ ${ }^{2}$ Département de biologie \& Centre d'études nordiques, Université Laval, Québec City, Québec G1V 0A6, Canada
}

\begin{abstract}
We investigated marine protist diversity from below the euphotic zone during 4 consecutive seasons (November 2003 to July 2004) from a fixed station in the Canadian Arctic (Franklin Bay, Beaufort Sea). DGGE analysis and 18S rRNA gene clone libraries showed that this mesopelagic protist community was dynamic, with marked changes in taxonomic and functional community composition in different seasons. The most frequently recovered sequences in autumn were related to heterotrophic dinoflagellates. In late December 2003, an abrupt change in the community composition occurred following an influx of water from the lower Pacific halocline that flowed onto the Arctic continental shelf and into Franklin Bay. Subsequently, the most frequently retrieved sequences matched uncultured marine alveolates, which are thought to be primarily parasites. This community changed little over the winter, with modest changes in spring marked by the addition of taxa. Summer libraries from 2004 were once more dominated by dinoflagellate sequences with a community very similar to that at the end of autumn 2003. These summer and autumn communities corresponded to periods of higher phytoplankton sedimentation rates in the euphotic zone. We suggest that the deep protist community may reform annually in response to primary production higher in the water column and that the winter mesopelagic protist community is dynamically coupled to the deep offshore ocean.
\end{abstract}

KEY WORDS: Mesopelagic $\cdot$ Seasonality $\cdot$ Eukaryotic parasites $\cdot$ Protists $\cdot$ Alveolates $\cdot$ Arctic marine environment · Franklin Bay · 18S rDNA · Molecular techniques · Phylogenetic diversity

\section{INTRODUCTION}

Despite the importance of marine microorganisms in global carbon, energy and nutrient cycling, factors controlling microbial community structure, and spatial and temporal distributions are not well understood (Martiny et al. 2006). The annual succession of protists, especially phytoplankton, has been widely studied in coastal and some open ocean regions (Larsen et al. 2004, Litchman et al. 2006). Many of these studies have been based on pigment signatures (Anderson et al. 2008); however, increasingly, environmental surveys using molecular clone libraries have been used to investigate seasonal changes in small eukaryotes (Romari \& Vaulot 2004, Medlin et al. 2006, Worden 2006). All have shown that different major groups dominate over different seasons. These studies have been largely restricted to the euphotic zone, where light and mixing are the key factors driving microbial community structure and dynamics. While several environmental surveys have reported eukaryote diversity from below the euphotic zone, the majority of these focused on very deep waters (Countway et al. 2007, Not et al. 2007) or hydrothermal vents (Edgcomb et al. 2002). There are few reports of protists in the mesopelagic zone, the region just below the photic zone (Lopez-Garcia et al. 2001, Not et al. 2007) and none with temporal resolution.

In the photic zone and upper mixed layer, productivity and microbial community composition are affected by temperature, light, nutrients, and hydrographic conditions (Sakshaug 2004, Greene \& Pershing 2007). Because of the wide fluctuations in physical and chemical conditions over the year, the surface microbial communities of Arctic waters have pronounced seasonal patterns (Sherr et al. 2003, Carmack et al. 2004), with surface microbial community seasonal succession 
mostly driven first by light (Terrado et al. 2008) and then by nutrients (Lovejoy et al. 2004). The paucity of data on the dynamics and diversity of microbes in the mesopelagic zone contrasts with its importance as a processing zone for sedimenting euphotic production, with direct implications for the export of carbon to the ocean floor (Michel et al. 2002). There is considerable heterotrophic activity in the mesopelagic zone (Biddanda \& Benner 1997), where protists play a significant role in carbon cycling and remineralization (Gowing et al. 2003, Tanaka \& Rassoulzadegan 2004). Microscopy-based techniques indicate that species composition and standing stocks of these protists vary seasonally (Gowing et al. 2003) and that heterotrophic activity is coupled to large phytoplankton in the euphotic zone (Simon et al. 2004). Given such close coupling, it is important to understand the seasonal dynamics of microbial community structure and function throughout the Arctic Ocean water column, since climate models predict future changes in circulation, stratification, temperature and ice cover in the Arctic (Cavalieri et al. 1997, Johannessen et al. 1999, Serreze et al. 2000).

The Canadian Arctic Shelf Exchange Study (CASES) provided an opportunity for the first time in the Arctic to sample from autumn to summer at a fixed station in offshore landfast ice. Our objectives for this study were to (1) investigate the protist diversity for the first time in an Arctic mesopelagic zone and (2) evaluate whether this protist community changed over seasons despite perpetual sub-photic irradiance and relatively stable conditions compared to the upper water column. We addressed these questions by way of molecular surveys using the fingerprinting technique of DGGE and by construction of 18S rRNA gene clone libraries.

\section{MATERIALS AND METHODS}

Sample collection. As part of the CASES program, the icebreaker CCGS 'Amundsen' was frozen into Franklin Bay $\left(70^{\circ} 1.3^{\prime} \mathrm{N}, 126^{\circ} 25.2^{\prime} \mathrm{W}\right.$, maximum depth $225 \mathrm{~m}$ ) for continuous biological and physical studies during winter 2003 and spring 2004. This permitted under-ice sampling of the water column every $6 \mathrm{~d}$ over nearly 6 mo. Samples were collected at discrete depths with a Seabird rosette system equipped with 121 Niskin-type bottles and a Seabird 911+ CTD probe. CTD salinity (S) was calibrated with water samples analyzed using a Guildline Auto-Sal salinometer. Values of potential temperature $(\theta)$ and potential density were computed using algorithms from UNESCO (Fofonoff \& Millard 1983). Fluorescence (Seapoint), transmissivity (WetLabs C-Star Transmissometer), photosynthetically available radiation $\left(\mathrm{PAR}_{i}\right.$ Biospheri- cal Instruments), and relative nitrate concentrations (Satlantic MBARI ISUS) were also recorded. Samples for this study were collected from below the Upper Pacific (or Arctic) Halocline (Rudels et al. 1994), between 160 and $200 \mathrm{~m}$. During the over-wintering period, water was sampled through the ship's moon pool, an opening to the ocean from inside the ship. Samples taken in early autumn and summer were also taken from the CCGS Amundsen using an identical rosette system mounted on an A-frame. Autumn and summer sampling was less frequent, since the Franklin Bay station was sampled in conjunction with a series of larger transects in the Beaufort Sea.

DNA collection and extraction. Samples for DNA analyses were collected from Niskin-type bottles into clean carboys after rinsing 3 times with sample water. Approximately $4 \mathrm{l}$ of water was immediately sequentially filtered through a $100 \mu \mathrm{m}$ mesh, a $3 \mu \mathrm{m}$ pore size, $47 \mathrm{~mm}$ polycarbonate (PC) filter (Millipore) and a $0.2 \mu \mathrm{m}$ pore size PC Sterivex unit (Millipore) by positive displacement using a peristaltic pump. The $3 \mu \mathrm{m}$ filters (large fraction) were placed into Cryovials with $2 \mathrm{ml}$ of buffer $(1.8 \mathrm{ml}$ of $40 \mathrm{mM}$ EDTA; $50 \mathrm{mM}$ Tris $\mathrm{pH}=$ $8.3 ; 0.75 \mathrm{M}$ sucrose). Similarly, the $0.2 \mu \mathrm{m}$ (small fraction) Sterivex units were filled with the same buffer at the end of the filtration. Both the large and small fractions were frozen immediately and stored at $-80^{\circ} \mathrm{C}$ until DNA extraction.

DNA was extracted using standard protocols. Cells were treated with lysozyme, proteinase $\mathrm{K}$ and sodium dodecyl sulfate, followed by a phenol-chloroformisoamyl alcohol extraction and redissolution of the final pellet in TE buffer. The solubilized DNA was concentrated with an Amicon Ultra-4100k MWCO concentration device (Millipore) and stored in a final volume of 100 to $200 \mu \mathrm{l}$. DNA quality and concentration were verified by agarose gel electrophoresis, and the extracted DNA was stored at $-80^{\circ} \mathrm{C}$ until further processing.

DGGE. The PCR amplification of sample DNA for the DGGE analyses was as described in Hamilton et al. (2008). Briefly, amplicons were obtained using general eukaryotic primers Euk1F and Euk516r-GC (GC clamp). The $25 \mu \mathrm{l}$ volume PCR reaction was carried out using a Bio-Rad iCycler thermal cycler, with $200 \mu \mathrm{M}$ of each deoxynucleotide triphosphate (dNTPs), each primer at a concentration of $0.3 \mu \mathrm{M}, 2.5$ units of Taq DNA polymerase (New England Biolabs) and the PCR buffer supplied with the Taq enzyme. DGGEs were run using a DGGE 2401-Rev B system (CBS Scientific Company). DGGE banding patterns were analyzed with Quantity One software (BioRad v. 4.6.0). PCR products of the same sample were rerun on separate gels, and the DGGE patterns were the same in terms of relative band intensity and band spacing. The band profiles of all lanes were converted into a matrix profile 
and each band was scored by its intensity relative to the total intensity of its lane, which has the effect of normalizing the differences between lanes and runs. Only bands with at least $10 \%$ of total lane intensity (determined using Quantity One binning protocols) were retained for analysis. The absence of a band in a lane was reported as a 0 . Cluster analysis of the relative intensity matrix was carried out using PAST software (Hammer et al. 2001).

Clone libraries. Eukaryotic 18s rRNA genes were amplified by PCR with the eukaryotic primers Euk $1 \mathrm{~F}$ (5'-AAC CTG GTT GAT CCT GCC AGT-3') and Euk B (5'-TGA TCC TTC TGC AGG TTC ACC TAC-3'), resulting in a ca. 1780 bp insert (Medlin et al. 1988). The $50 \mu \mathrm{l}$ PCR reactions contained $200 \mu \mathrm{M}$ of each dNTP, $0.3 \mu \mathrm{M}$ of each primer, 2.5 units of Taq DNA polymerase (New England Biolabs), PCR buffer supplied with the enzyme and environmental DNA as template. Reactions were carried out in a BioRad iCycler with the following cycle: an initial denaturation at $94^{\circ} \mathrm{C}$ for $3 \mathrm{~min}, 30$ cycles of denaturation at $94^{\circ} \mathrm{C}$ for $45 \mathrm{~s}$, annealing at $55^{\circ} \mathrm{C}$ for $1 \mathrm{~min}$, extension at $72^{\circ} \mathrm{C}$ for $3 \mathrm{~min}$, and a final extension at $72^{\circ} \mathrm{C}$ for $10 \mathrm{~min}$. Three separate PCR products for each library derived from 3 different template concentrations (non-diluted, diluted 1:10 and diluted 1:100) were pooled, then cleaned and concentrated using a QIAquick PCR purification Kit (Qiagen), following the manufacturer instructions. An aliquot of each concentrated PCR product was ligated into the vector ( $p C R$ 2.1) supplied with the TOPO TA cloning kit (Invitrogen) and used to transform competent Escherichia coli cells following the manufacturer's instructions. Putative positive colonies were picked and transferred to 96-multiwell plates with LuriaBertani medium, ampicillin and $7 \%$ glycerol and incubated 8 to $16 \mathrm{~h}$ at $37^{\circ} \mathrm{C}$ before being stored at $-20^{\circ} \mathrm{C}$ until screening.

One 96-well plate for each library was screened and clone inserts were verified by PCR amplification using the same primers as for the clone libraries (Euk $1 \mathrm{~F}$ and Euk B). Resulting PCR amplicons were then digested with 1 standard unit (U) of the restriction enzyme HaeIII (New England Biolabs) for $16 \mathrm{~h}$ at $37^{\circ} \mathrm{C}$. Images of restriction fragment length polymorphism (RFLP) patterns were acquired with the Bio-Rad Gel Doc imaging system and analyzed with Quantity One software (Bio-Rad v.4.6.0) following electrophoresis on a $2.5 \%$ low melting point agarose gel. We ran $100 \mathrm{bp}$ ladders (Invitrogen) with the samples enabling comparisons of the RFLP patterns of different gels. Clones with the same RFLP pattern were grouped together and at least 1 representative of each pattern was sequenced by the Plateforme de séquençage et génotypage du Centre hospitalier de l'Université Laval (CHUL), with a ABI 3730xl system (Applied Biosys- tems) using the primer 528F (5'-GCG GTA ATT CCA GCT CCA A-3'). All sequences were manually checked and only high quality sequences with no ambiguous base pairs were retained for further analysis.

Taxonomic affiliation and phylogenetic analyses. Sequences were compared to those in the GenBank database using the BLASTN server (Altschul et al. 1990). Sequences with low BLAST scores were tested using the Check Chimera program at the Ribosomal Data Project II (Michigan State University; http:// rdp8.cme.msu.edu/cgis/chimera.cgi?su=SSU). Additionally, the software package KeyDNAtools was used to identify possible chimeras and obtain preliminary taxonomic affiliations (Guillou et al. 2008). Sequences that passed chimeric screening were phylogenetically grouped using Clustal X v.1.83 (Thompson et al. 1997). Alignments were checked using BioX v. $1.5 \mathrm{dev}$ (http://www.lagercrantz.name/software/biox/). Only informative regions were kept for the final alignments after being trimmed using G-Blocks with a minimum block of five and allowed gap positions equal to half (Talavera \& Castresana 2007) (http://molevol.cmima. csic.es/castresana/Gblocks_server.html). Neighborjoining trees with bootstrap were built using the software PAUP v. $4.0 \mathrm{~b} 10$ (Sinauer Associates). DNADIST from PHYLIP was used to calculate genetic distances with the Kimura-2 model (Felsenstein 2005). Rarefaction curves, operational taxonomic units (OTUs, defined as $<2 \%$ difference between sequences) and diversity indexes were calculated with DOTUR (Schloss \& Handelsman 2005). Cluster analysis was carried out using the PAST software (Hammer et al. 2001). Sequences from this study are available from GenBank under accession numbers FJ169684 to FJ169852 and FJ775605 to FJ775666.

\section{RESULTS}

\section{Hydrography}

Water column dynamics of Franklin Bay during the CASES program from 2003 to 2004 have been described in detail elsewhere (Benoit et al. 2008, Forest et al. 2008). Briefly, during winter and spring the water column was ice covered while in autumn and summer the region was ice-free. Three distinct water masses persisted throughout the sampling period (Fig. 1). During winter, the upper surface mixed layer (top 30 to $40 \mathrm{~m}$ ) was above a temperature inversion, where warmer water intruded between 2 colder water masses. In summer, this upper surface layer was above $0^{\circ} \mathrm{C}$ and no temperature inversion was present. The upper part of the Pacific halocline lay below this surface layer, with a salinity of 32 to 33 ; the depth of the 


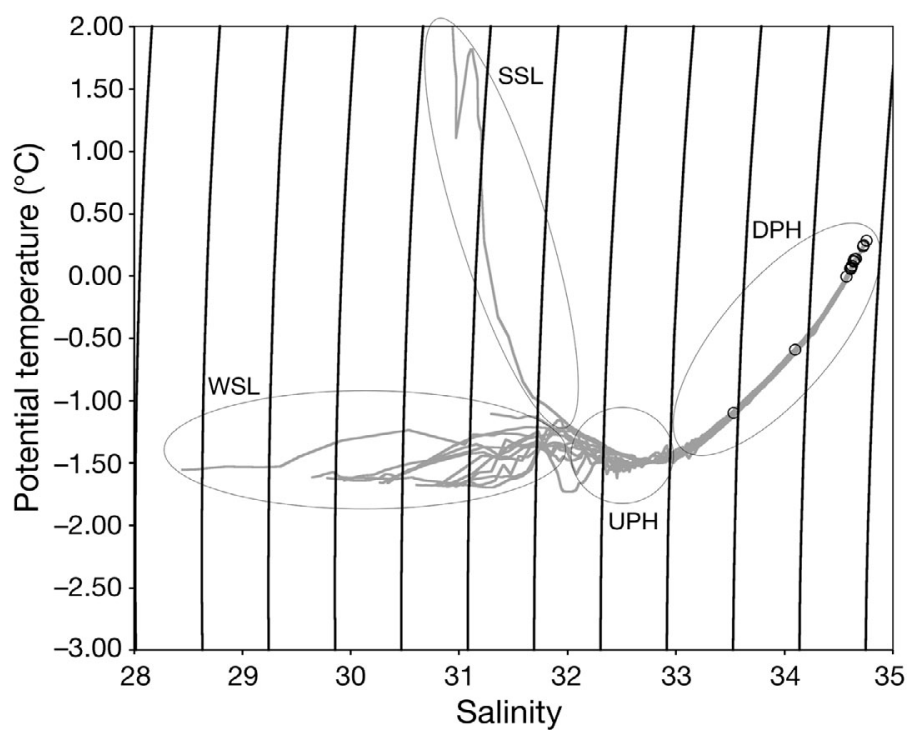

Fig. 1. Temperature and salinity of water masses in Franklin Bay: winter surface layer (WSL), summer surface layer (SSL), upper Pacific halocline (UPH), and deep Pacific halocline (DPH). Grey lines: temperature-salinity (T-S) profiles of casts; grey circle and ovals: different water masses; open black circles the characteristics of the discrete bottle samples used in this study (all samples taken from the DPH). The nearly parallel lines are the T-S lines of constant density

Pacific halocline layer varied over the year, with a maximum extent to $140 \mathrm{~m}$ in May 2004. Below this was a layer of water with higher salinity $(>33)$ and relatively warmer temperatures (range $-1.25^{\circ} \mathrm{C}$ to $0^{\circ} \mathrm{C}$ ). This deep Pacific halocline (DPH) layer continued to the bottom of the Franklin Bay water column (225 m). All samples for this study were collected from this deepest layer (DPH in Fig. 1, Table 1).

Table 1. Samples used for the DGGE analysis with the sampling depth (m), temperature $\left({ }^{\circ} \mathrm{C}\right)$ and salinity. Clone library names are indicated in the selected samples as well as the name for the sample. Note that the last letter of each clone library name corresponds to the size fraction used to construct the library: small

(S) or large (L), see 'Materials and methods.' Dates given as d/mo/yr

\begin{tabular}{|lrrrl|}
\hline Date & Depth & Temperature & Salinity & Clone Library (season) \\
\hline $19 / 11 / 2003$ & 161 & -1.10 & 33.53 & CS050S, CS050L (autumn) \\
$16 / 12 / 2003$ & 217 & 0.28 & 34.76 & \\
$22 / 12 / 2003$ & 219 & 0.23 & 34.73 & CS060S, CS060L (winter) \\
$03 / 01 / 2004$ & 218 & 0.25 & 34.73 & \\
$10 / 01 / 2004$ & 219 & 0.14 & 34.66 & \\
$28 / 01 / 2004$ & 220 & 0.07 & 34.62 & \\
$26 / 02 / 2004$ & 220 & 0.05 & 34.61 & \\
$03 / 03 / 2004$ & 223 & 0.08 & 34.62 & \\
$27 / 03 / 2004$ & 223 & 0.11 & 34.64 & \\
$22 / 04 / 2004$ & 225 & 0.06 & 34.61 & CS123S, CS123L (spring) \\
$15 / 05 / 2004$ & 219 & -0.01 & 34.57 & \\
$21 / 05 / 2004$ & 220 & 0.13 & 34.65 & \\
$27 / 05 / 2004$ & 219 & 0.12 & 34.64 & \\
$16 / 07 / 2004$ & 219 & -0.59 & 34.10 & CS163S, CS163L (summer) \\
& & & & \\
\hline
\end{tabular}

\section{DGGE fingerprinting}

As a first assessment of the temporal changes in the mesopelagic microbial community from November 2003 to July 2004, 14 samples from the large size fraction $(>3 \mu \mathrm{m})$ were analyzed by DGGE (Table 1$)$. The well-separated bands indicated distinct community patterns that changed over time (Fig. S1, available as AME Supplementary Material at: www.int-res.com/ articles/suppl/a056p025_app.pdf). For each sample, 3 to 12 bands fell within our selection criteria, bands with at least $10 \%$ of the total relative intensity, giving a total of 22 different OTUs. Two main clusters emerged from the banding profile matrix: 1 included the samples from November 2003 and July 2004 and the second included all samples from winter and spring (Fig. 2A).

\section{Clone libraries}

Autumn, winter, spring and summer clone libraries of the small $(<3 \mu \mathrm{m})$ and large $(>3 \mu \mathrm{m})$ fractions were constructed (Table 1). Following our screening, 515 positive clones containing the ca. $1780 \mathrm{bp}$ insert were identified from the 8 clone libraries. At least 1 representative of each RFLP pattern in each clone library was sequenced. Of these, 12 sequences were considered to be chimeras and were excluded from further analysis. Coverage values were higher than $65 \%$ for all samples (Table 2). Rarefaction curves did not reach an asymptote (Fig. S2, available as AME Supplementary Material at: www.int-res.com/articles/suppl/a056p025_app.pdf) and Chao I and ACE diversity estimators were higher than the number of recovered OTUs (Table 2). For these 2 estimators, the summer and autumn libraries were more diverse. However, Shannon and Simpson indexes indicated that the spring libraries were comparatively more diverse (Table 2). Cluster analysis of the distribution of the OTUs among the samples grouped the winter and spring samples together and the summer and autumn samples together (Fig. 2B).

Overall, more than $80 \%$ of the clones belonged to the Alveolata. Stramenopiles and Radiolaria were the next most commonly retrieved groups (Table 3). Alveolate sequences fell within 6 major groups: marine alveolate Group I, marine alveolate Group II, marine alveolate Group III (from Guillou et al., 2008), Ciliophora, Dinophyceae and a single Ellobiopsidae clone in spring (sequence CS060S14). 

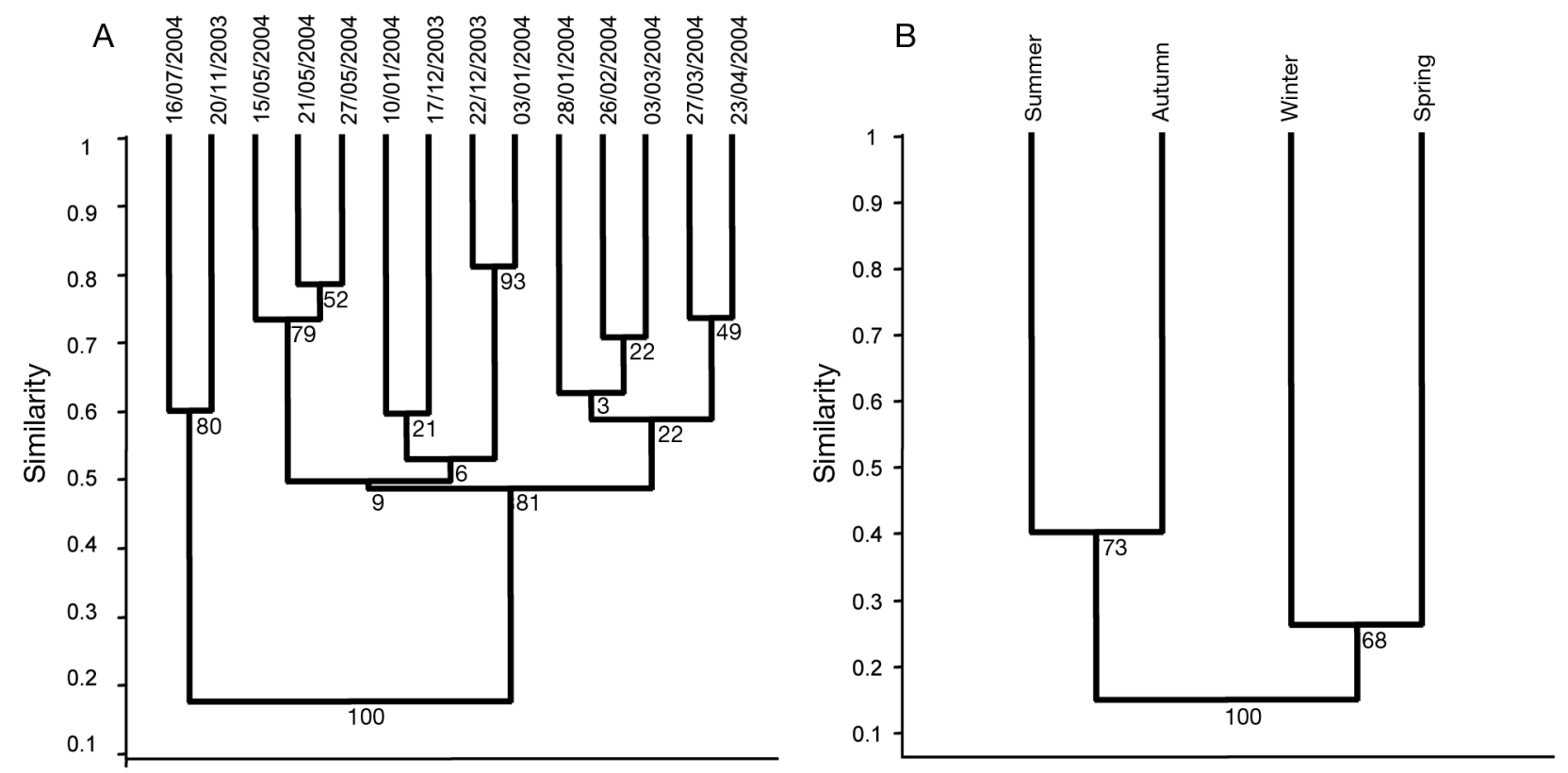

Fig. 2. Cluster analysis (Bray Curtis) with bootstrap values $(\mathrm{n}=1000)$. (A) Analysis of the DGGE band matrix. (B) Analysis of the operational taxonomic units (OTUs) distribution in the 4 samples where clone libraries were constructed. OTUs were defined at the $2 \%$ difference level. Bootstrap values $>50$ are noted at the relevant nodes. Dates are given as $\mathrm{d} / \mathrm{mo} / \mathrm{yr}$

Table 2. Diversity of the deep eukaryotic assemblage in Franklin Bay during 4 seasons. 'All' indicates the results from the combined libraries. Enumeration of operational taxonomic units (OTUs) and calculation of diversity estimators were at the $2 \%$ distance level. Coverage $=1-(\mathrm{n} 1-\mathrm{N})$ where $\mathrm{n} 1$ is the number of clones which occurred only once in a library of $\mathrm{N}$ clones, expressed as percentage (Good 1953). The $95 \%$ CIs for ACE and Chao I are given in parentheses

\begin{tabular}{|lcccccrc|}
\hline Sample & Clones & OTUs & Coverage & ACE & Chao I & Shannon & Simpson \\
\hline Autumn & 112 & 28 & 75.0 & $59(38-123)$ & $50(34-100)$ & 2.04 & 0.29 \\
Winter & 126 & 21 & 83.3 & $35(25-71)$ & $30(23-59)$ & 2.04 & 0.22 \\
Spring & 109 & 37 & 66.1 & $56(43-89)$ & $48(40-75)$ & 3.18 & 0.05 \\
Summer & 156 & 38 & 75.6 & $59(44-98)$ & $61(44-17)$ & 2.73 & 0.12 \\
All & 503 & 91 & 81.9 & $178(137-253)$ & $163(125-245)$ & 3.38 & 0.08 \\
\hline
\end{tabular}

Table 3. Number of clones in each clone library that contributed to first rank taxonomic groups (Adl et al. 2005)

\begin{tabular}{|c|c|c|c|c|c|c|c|c|}
\hline \multirow{2}{*}{ Group } & \multicolumn{2}{|c|}{ - Autumn - } & \multicolumn{2}{|c|}{- Winter -} & \multicolumn{2}{|c|}{$\longrightarrow$ Spring $\longrightarrow$} & \multicolumn{2}{|c|}{ Summer } \\
\hline & CS050S & CS050L & CS060S & CS060L & CS123S & CS123L & CS163S & CS163L \\
\hline Alveolata & 34 & 53 & 63 & 41 & 23 & 35 & 54 & 69 \\
\hline Cercozoa & 0 & 0 & 0 & 0 & 1 & 3 & 0 & 0 \\
\hline Cryptophyceae & 0 & 1 & 0 & 0 & 0 & 0 & 0 & 0 \\
\hline Euglenozoa & 0 & 0 & 0 & 0 & 2 & 3 & 0 & 2 \\
\hline Flavellinea & 0 & 0 & 0 & 0 & 0 & 0 & 1 & 0 \\
\hline Fungi & 0 & 0 & 0 & 0 & 0 & 0 & 5 & 0 \\
\hline Mesomycetozoa & 2 & 1 & 0 & 0 & 1 & 0 & 0 & 0 \\
\hline Metazoa & 1 & 4 & 2 & 3 & 0 & 1 & 1 & 2 \\
\hline Radiolaria & 3 & 3 & 1 & 13 & 2 & 6 & 10 & 2 \\
\hline Stramenopiles & 7 & 3 & 1 & 2 & 18 & 14 & 5 & 5 \\
\hline Total & 47 & 65 & 67 & 59 & 47 & 62 & 76 & 80 \\
\hline
\end{tabular}


We recovered Group II marine alveolates from throughout the year; however, they were rarer in the autumn and summer libraries (Fig. 3). Sequences fell into eight different sub-clusters defined by Groisillier et al. (2006) and Guillou et al. (2008) (Fig. 3). Overall, ca. $43 \%$ of winter sequences and $22 \%$ of spring sequences fell into sub-cluster 6 . Cluster 7 sequences were recovered from all seasons, with more in spring, accounting for $11 \%$ of the spring sequences, but also ca $13 \%$ of the summer sequences. One cluster containing $20 \%$ of the winter sequences and $4 \%$ of the spring sequences did not fall into any previously established clusters and we have designated this as an Arctic cluster (Fig. 3).

Group I alveolates were not especially abundant in any season, with maximal occurrence in summer.

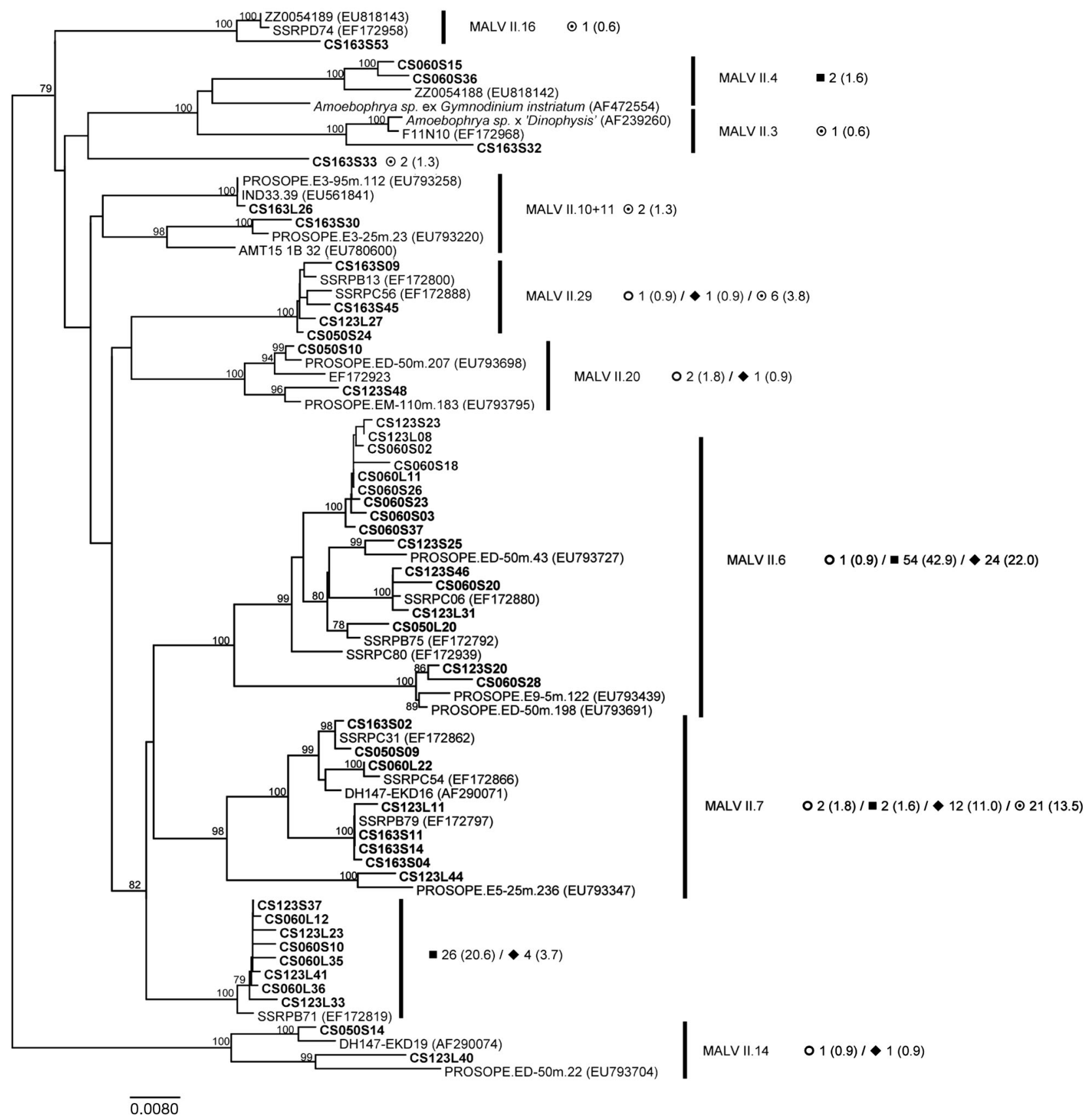

Fig. 3. Marine alveolate Group II (MALVII) neighbor-joining tree from partial sequences with bootstrap values $>75(\mathrm{n}=1000)$ at nodes; sequences from this study are in boldface. We retained 872 positions for the construction of the tree. GenBank accession numbers for reference sequences are given in parentheses. Outgroup (AB120003) has been removed. Numbers of clones and percentages (in parentheses) are given for autumn (O), winter $(\mathbf{\square})$, spring $(\diamond)$ and summer $(\odot)$ 
These sequences all fell into previously defined clusters (Guillou et al. 2008) and, though no single cluster accounted for more than $3 \%$ of all sequences in any season, they made up $7 \%$ of the total clones (Fig. 4A).
Novel Group III alveolates (Guillou et al. 2008) had only a few representatives, all from spring (Fig. 4B).

Dinophyceae were more abundant in clone libraries from autumn and summer, with a cluster related to
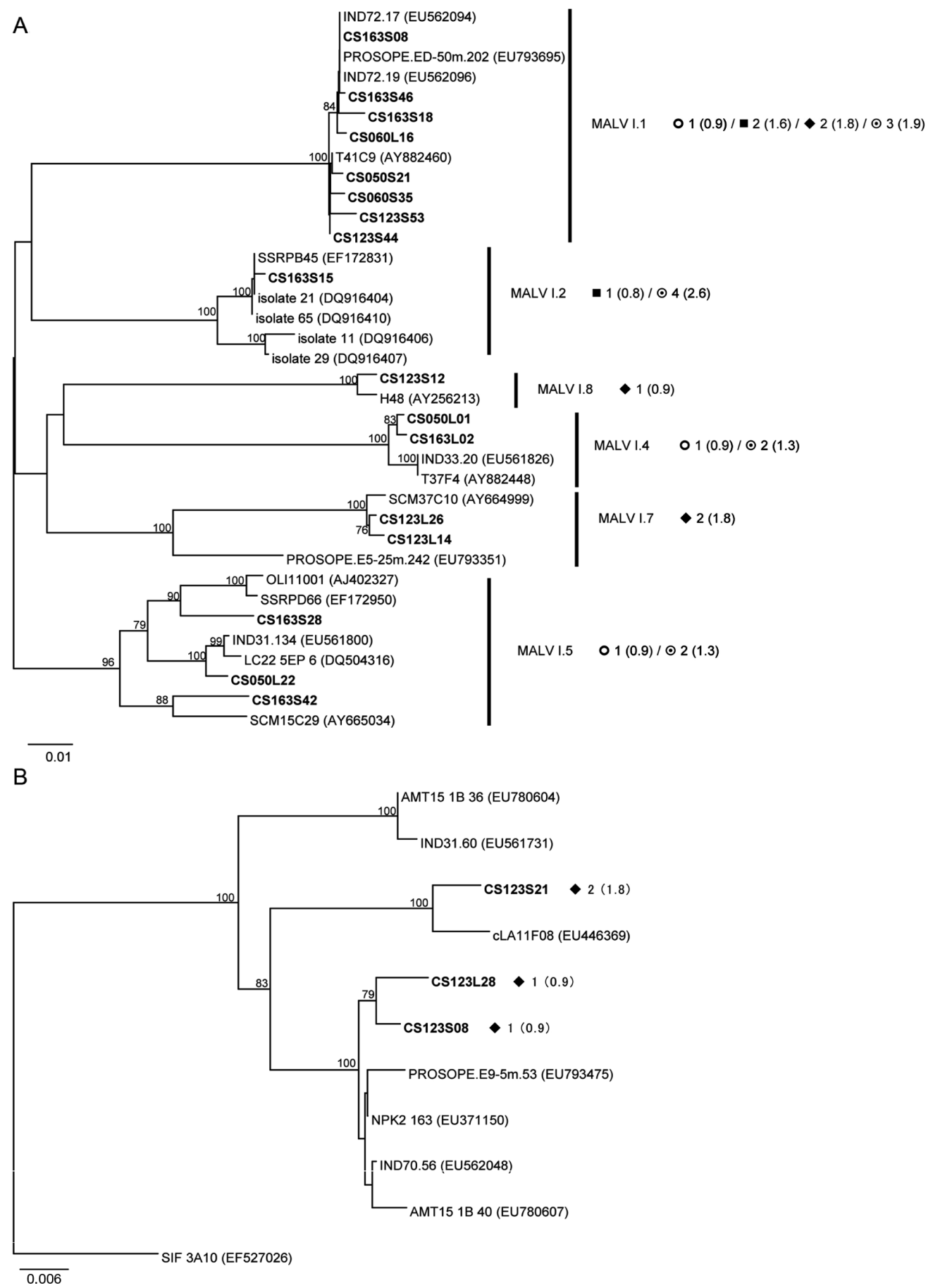

Fig. 4. Neighbor-joining phylogenetic trees from partial sequences with bootstrap values $>75(\mathrm{n}=1000)$ at nodes; sequences from this study are in boldface. GenBank accession numbers for reference sequences are given in parentheses. The outgroup (AB120003) has been removed for clarity. (A) Marine alveolate Group I (MALV I); 872 positions were retained for the construction of the tree. (B) Marine alveolate Group III tree; 841 positions were retained. Numbers of clones and percentages (in parentheses) are given as in Fig. 3 
Gyrodinium rubrum in particular accounting for almost half of the autumn sequences and a third of summer sequences (Fig. 5A). Ciliophora sequences were rarer, mostly recovered from summer libraries (Fig. 5B). The majority of these sequences were related to the environmental cluster StromB (Lovejoy et al. 2006), accounting for $7 \%$ of summer sequences

Stramenopile sequences were retrieved from all clone libraries, although in spring they were more diverse and were a higher percentage of total sequences (Table 3, Fig. 6). In the spring libraries Dictyochophyceae accounted for $10 \%$ of the sequences but were not recovered in other seasons. Chrysophyceae sequences were also common in the spring libraries, accounting for ca. $6 \%$ of sequences, with several sequences also recovered in autumn. Diatom (Bacillariophyceae) sequences were retrieved only in summer and autumn, accounting for fewer than $4 \%$ of total sequences, while a total of 4 sequences from the closely related Bolidophyceae, were retrieved in winter, spring and autumn. Among presumed heterotrophic stramenopiles, Bicosoecida were only retrieved in

A

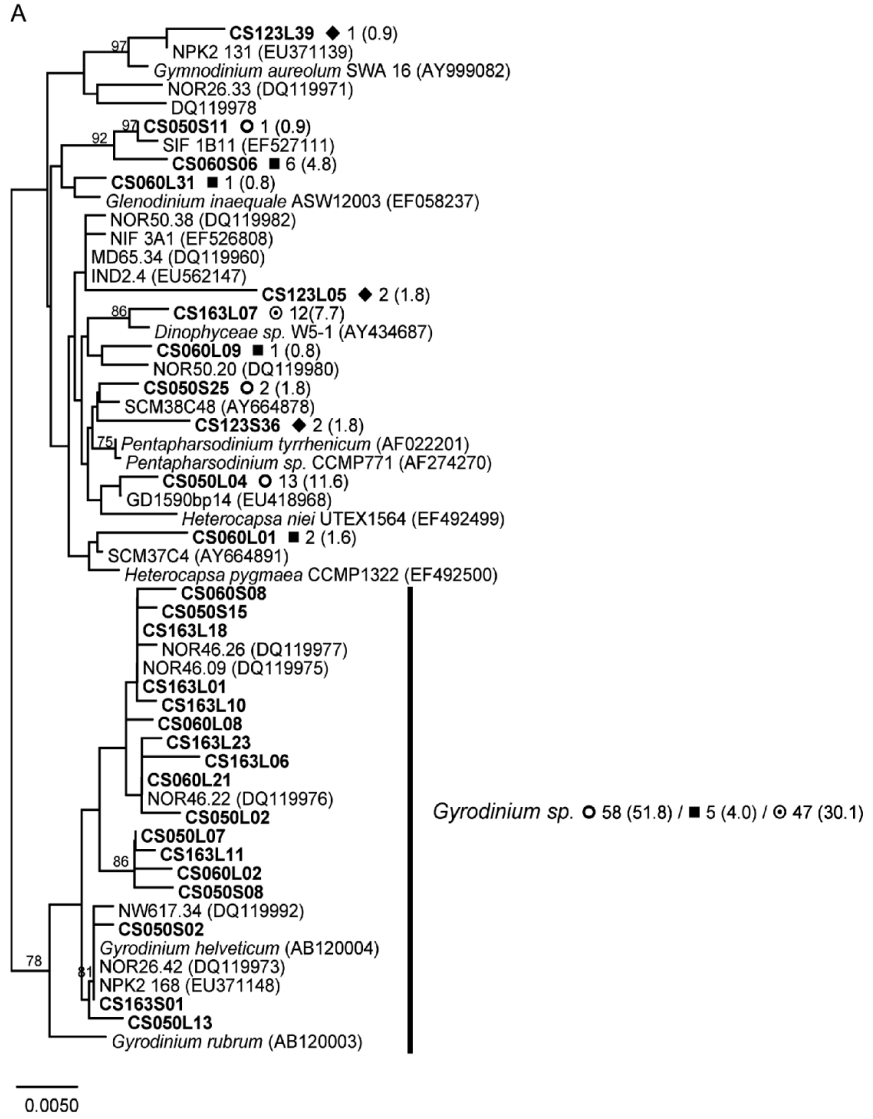

spring with 5 sequences total, and uncultivated marine stramenopiles (MAST) were relatively rare, with different clusters retrieved from different seasons, except MAST 1A (Massana et al. 2004), which was represented at least by 1 sequences each season.

Radiolarian sequences were recovered from all clone libraries. A cluster of sequences belonging to the Acantharea (cluster ACAN I in Fig. 7) contained sequences from all 4 seasons. Other radiolarian sequences fell within the Spumellarida, most of which were associated with the environmental clusters RAD III, RAD IV and RAD V (Not et al. 2007). RAD III sequences were especially abundant in winter, accounting for ca. $9 \%$ of the winter sequences (Fig. 7).

Other groups in the clone libraries accounted for fewer than 2 sequences in any season (Table S1, available as AME Supplementary Material at: www.intres.com/articles/suppl/a056p025_app.pdf). One Cercozoa sequence (CS123L30), most closely related to Cryothecomonas longipes (AF290540, BLAST score 1659, identity of $98 \%$ ), was recovered in the spring clone library. Also, only 1 Cryptophyceae sequence

B

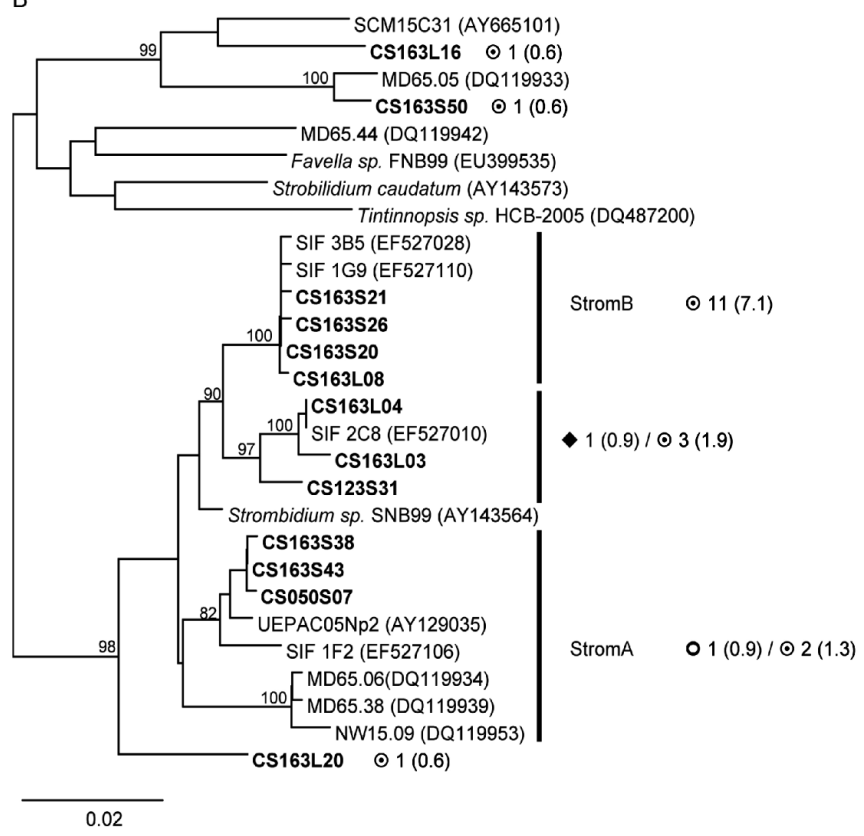

Fig. 5. Neighbor-joining phylogenetic trees from partial sequences with bootstrap values $>75(\mathrm{n}=1000)$ at nodes; sequences from this study are in boldface. GenBank accession numbers for reference sequences are given in parentheses. The outgroups were removed for clarity. (A) Dinophyceae (outgroup AF069516); 653 positions were retained for the construction of the tree. (B) Ciliophora (outgroup AB120003); 735 positions were retained for the construction of the tree. Numbers of clones and percentages (in parentheses) are given as in Fig. 3 


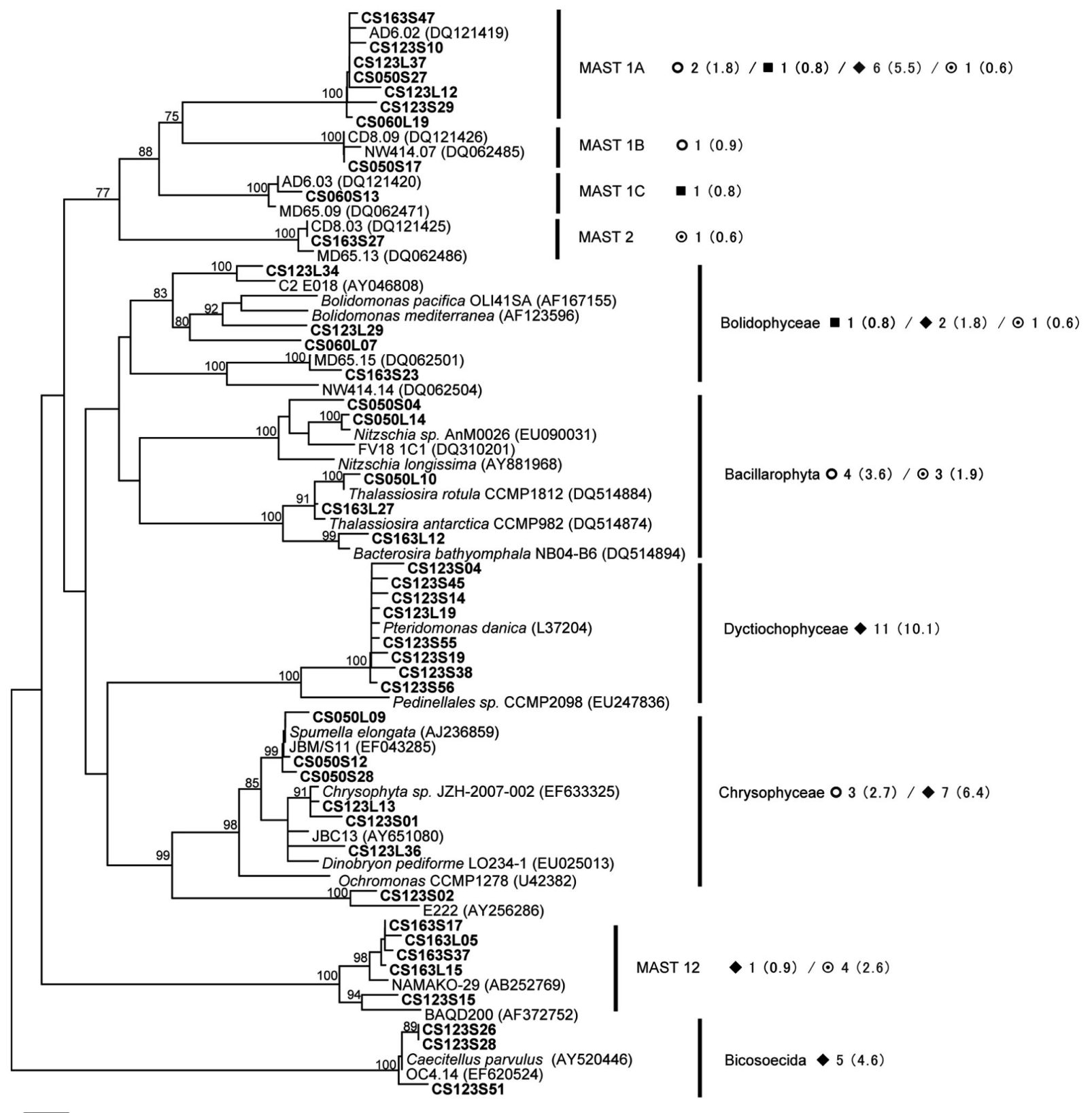

$\overline{0.0080}$

Fig. 6. Stramenopiles neighbor-joining phylogenetic tree from partial sequences with bootstrap values $>75(\mathrm{n}=1000)$ indicating the overall position of sequences from this study (boldface). We retained 808 positions for the construction of the tree. GenBank accession numbers for reference sequences are given in parentheses. The outgroup (AB120003) has been removed. Numbers of clones and percentages (in parentheses) are given as in Fig. 3

from the autumn clone library was recovered (CS050L18). This sequence was most closely related to environmental sequences and the closest cultured organism was Geminigera cryophila (DQ452091, BLAST score 1659, identity 99\%). Euglenozoan sequences were found in the spring and summer clone libraries. The spring sequences all belonged to the Kinetoplastida group, while the summer sequences belonged to the Diplonemida group. Choanoflagel- lates were retrieved from both autumn and spring, and were most closely related to environmental sequences, with the closest known species being Diaphanoeca grandis. Fungal sequences were retrieved only from summer, mostly Ascomycota with 1 Chytridiales. Metazoan sequences were retrieved from all clone libraries, with sequences related to different major groups, especially polychaetes and hydrozoa (Table S1). 


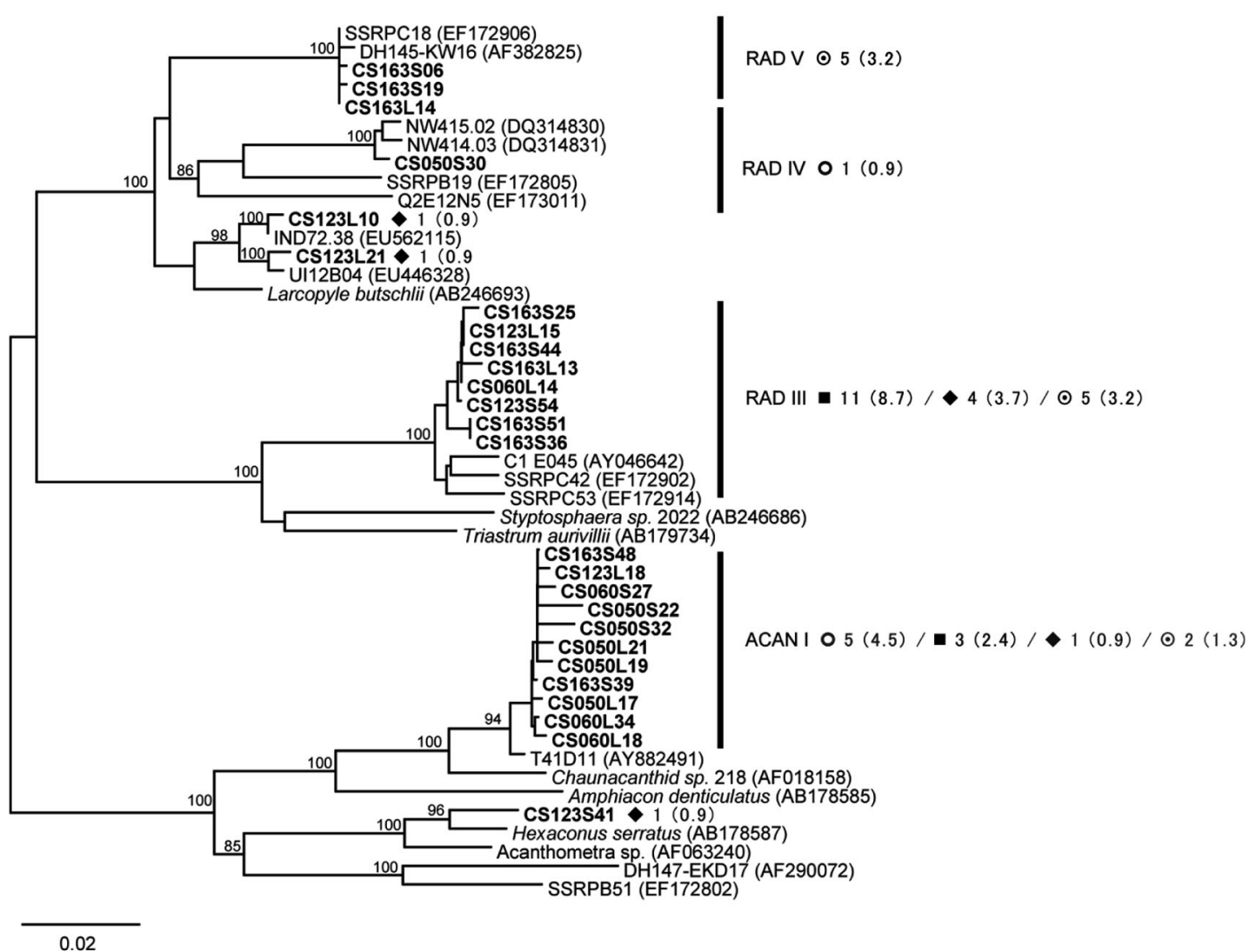

Fig. 7. Radiolaria neighbor-joining tree from partial sequences with bootstrap values $>75(\mathrm{n}=1000)$ at nodes; sequences from this study are in boldface. We retained 807 positions for the construction of the tree. GenBank accession numbers for reference sequences are given in parentheses. The outgroup (AF411286) has been removed. Numbers of clones and percentage (in parentheses) are given as in Fig. 3

\section{DISCUSSION}

\section{Phylogenetic diversity}

A primary objective of this study was to investigate protist communities in the Arctic mesopelagic zone using environmental DNA collected from Franklin Bay. To achieve this we constructed 8 clone libraries from 4 seasons from both large $(>3 \mu \mathrm{m})$ and small fractions ( 3 to $0.2 \mu \mathrm{m}$ ). Since our aim was to compare samples from the same environment but at different seasons, we used the same extraction and amplification protocols, and standardized our approach for the 4 seasons, including constructing clone libraries from 2 size categories. The aim of this study was not to unveil the whole diversity of the sample, but rather to compare seasons and identify phylotypes characteristic of the communities.

Environmental surveys of SSU rRNA were first applied to marine Eubacteria and then Archaea, as the only means to identify small phenotypically similar microbes without cultivation (DeLong et al. 1993, Murray et al. 1998). Subsequently it was determined that there were many small phytoplankton and other protists in marine waters (Lopez-Garcia et al. 2001) equally intractable using light microscopy. A number of studies were subsequently published with the aim of identifying this neglected community (Vaulot et al. 2008). Since the primary goal of those studies was to uncover picoplankton in the ocean, samples were routinely prefiltered (filter sizes ranged from 2 to $5 \mu \mathrm{m}$, but were most often $3 \mu \mathrm{m})$, and typically only the smaller size fraction was used for clone library construction. An interesting observation from nearly all of those studies was that while the target small cells were frequently matched to truly small cells, larger protists and even metazoans were also consistently amplified as well (Lovejoy et al. 2006, Vaulot et al. 2008). Here, our approach was to construct libraries from both size fractions. We found that overall the larger size fraction samples tended to amplify mostly classically larger protists (Radiolaria, Dinophycaea, ciliates) but recovered fewer strictly small cells, with the opposite for the smaller size fraction (Table S1). The overlap from the same sample was substantial and for this reason we chose to compare the seasonal differences using the combined re- 
sults of both size fractions. This overlap is likely due to a number of factors, including breakage of larger cells, which then pass through the prefilters, and conversely smaller cells adhering to particles or marine snow and remaining on the $3 \mu \mathrm{m}$ filter. This and other factors such as variable copy number of the 18S rRNA genes in different protists (Zhu et al. 2005) means that absolute cell number and biomass of the different protists cannot be estimated from clone libraries. There are additional biases in PCR-based approaches and the total biodiversity of mixed assemblages is not likely to be recovered using such approaches. The use of multiple primers and sample enrichment has been suggested as a means of reducing such bias (Behnke et al. 2006). Although it is unlikely that PCR-based surveys of the microbial diversity will ever find the total biodiversity present in a sample (Pedrós-Alió 2006), the use of a single set of primers can identify a large enough subset of protists to differentiate communities (Potvin \& Lovejoy 2009). As with most studies using PCR and cloning approaches, rarefaction curves (Fig. S2) and coverage values (Table 2) indicated that we undersampled the protist community. This was confirmed by the diversity estimators, which were higher than the OTUs detected in the clone libraries (Table 2). We detected diversity differences among seasons with higher Chao I and ACE values in summer and autumn compared to winter and spring. The Shannon and Simpson indexes, better indicators of evenness, were higher for the spring sample. Interestingly, although the water column was still covered by ice and snow, chlorophyll a ( $\mathrm{chl} \mathrm{a}$ ) concentrations began to increase in Franklin Bay in April (Terrado et al. 2008), and the diversity of protists in the deep water may have already begun to change slowly. All of the diversity indexes indicated that the deep community was least diverse in winter, when the upper water column was at its most quiescent.

The most abundant clones recovered from deep Franklin Bay belonged to the Alveolates (Table 3), as often reported in other environmental 18S rRNA gene surveys (Vaulot et al. 2008). Alveolates are a phenotypically diverse group that includes, among others, ciliates, dinoflagellates and uncultivated representatives from several taxonomically divergent groups, referred to as marine alveolates. These were first described from environmental clone libraries, the majority falling within 2 major clades designated Group I and Group II (Lopez-Garcia et al. 2001). Group II marine alveolates were later found to cluster with a previously described order of the Dinophyceae, the Syndiniales that include Amoebophrya spp., parasites of marine dinoflagellates (Skovgaard et al. 2005). Group I marine alveolates have also recently been linked with other marine parasites (Harada et al. 2007). Recently Guillou et al. (2008) analyzed thousands of environmental sequen- ces and all available sequences previously associated with Syndiniales. In addition to the Group I and II, they separated 3 additional higher-level clusters of marine alveolates. They reported that Group III and Group V contained only environmental clones and group IV included the described species of Syndinium and Hematodinium, parasites of zooplankton, and some environmental clones. Among the Group II alveolates, Guillou et al. (2008) defined 44 sub-clusters and within Group I 8 sub-clusters were identified. Interestingly, no ecological or geographic distribution patterns were discerned except perhaps a few small clusters that were mostly from anoxic marine environments (Guillou et al. 2008).

Group II marine alveolate sequences previously retrieved from stations on opposite sides of the Arctic were all from the summer upper mixed layer of the water column (Lovejoy et al. 2006). Guillou et al. (2008) placed these into 8 different clusters $(1,4,5,6,10$ \& 11, 14, 21, and 30). We found here that the Group II sequences from deep Franklin Bay were equally diverse and could be placed into 9 separate clusters: 3 , $4,6,7,10 \& 11,14,16,20,29$ and a novel Arctic cluster. There was some overlap between the 2 studies, with a few clades in common $(6,10$ \& 11 and 14); these shared clusters are also among the most frequent clades reported worldwide by Guillou et al. (2008). These authors also noted that Clade 7 , which was abundant in deep Franklin Bay, was more abundant at aphotic depths. Although the small subunit rRNA gene in general is rarely sufficient to identify ecotypes without corroborative evidence (Johnson et al. 2006, Webb et al. 2009), our novel Arctic clade may well be a candidate Arctic ecotype, perhaps parasitizing a uniquely Arctic host. While it is possible that many or most of these putative parasites have global distributions and little prey specificity, as suggested by Guillou et al. (2008), the existence of ecotypes or more specialized hostparasitoid systems should not be ruled out without more careful analysis of the whole ribosomal gene and other genes that may play a direct role in parasitism.

Given that most known marine alveolate sequences are related to parasitic genera (Skovgaard et al. 2005, Groisillier et al. 2006, Harada et al. 2007, Skovgaard \& Daugbjerg 2008), an important challenge is to identify the hosts. Potential hosts could include sarcodines, dinoflagellates, ciliates, crustacea, fishes or radiolarians (Coats 1999, Dolven et al. 2007). Not et al. (2007) suggested a possible relationship between abundant marine alveolate Group II deep sequences and radiolarian sequences. We too found that radiolarian sequences were most abundant in winter, with spring and summer having similar percentages and few sequences in autumn. The identity of the host of these putative parasites remains speculative and sequencing 
parasites from known hosts is required (Coats \& Park 2002, Skovgaard et al. 2005, Skovgaard \& Daugbjerg 2008).

Dinoflagellate sequences fell mostly into a single clade that includes Gyrodinium helveticum (Penard) Takano et Horiguchi and Gyrodinium rubrum (Kofoid et Swezy) (Fig. 5A). The polyphyletic genera Gymnodium and Gyrodinium are the most commonly described species of naked dinoflagellate genera (Saldarriaga et al. 2001) and their taxonomy is gradually being revised. Molecular studies have shown that $G$. helveticum and G. rubrum, together with Gyrodinium spirale and Gyrodinium fusiforme form a single monophyletic clade (Takano \& Horiguchi 2004), despite G. helveticum being considered a freshwater species and G. rubrum marine. Similarly, other environmental marine sequences from the Arctic (Lovejoy et al. 2006), as well as freshwater environmental sequences (Richards et al. 2005), group within this cluster, suggesting that this group is widely distributed and perhaps among those that switch easily between marine and freshwater environments (Logares et al. 2007).

Most Ciliophora sequences were related to Strombidium spp. and grouped with 2 environmental clusters from Arctic waters (StromA and StromB) previously described by Lovejoy et al. (2006) (Fig. 5B). Morphologically, ciliates are among the best-known and taxonomically well-defined groups of protists (Finlay 2004). On the other hand, the morphospecies concept usually applied to ciliates hides a diversity of ecotypes (Finlay et al. 2006), and novel environmental clades are frequently recovered from molecular surveys (Stoeck et al. 2003, Behnke et al. 2006, Lovejoy et al. 2006). The StromA and StromB clusters consistently retrieved from Arctic waters may signal the existence of polar-adapted ecotypes of Strombidium spp.

Stramenopile sequences were recovered in all clone libraries, but the greatest diversity and abundance of clones was found in spring. Diatom sequences were recovered in autumn and summer, likely sedimenting cells from the euphotic zone. Although diatom biomass in the upper mixed layer had started to increase in late spring (Terrado et al. 2008), the vertical flux of diatoms was significant only in summer and autumn (Forest et al. 2008). Heterotrophic stramenopiles included sequences related to the bicosoecid Cafeteria sp., the dictyochophyte Pteridomonas sp., the heterotrophic chrysophyte Spumella sp. and the environmental groups of marine stramenopiles (MAST) MAST-1A, MAST-1B, MAST-2 and MAST-12 (Massana et al. 2004). The putative bacterivorous MAST-1A have previously been retrieved almost exclusively in the euphotic zone (Not et al. 2007), with the exception of 1 sequence (DH144-EKD10; Lopez-Garcia et al. 2001). Massana et al (2006) reported that MAST-1A esti- mated from fluorescent in situ hybridization (FISH) were abundant in surface waters throughout the world ocean, except in the Arctic, where their abundance was low despite good representation in clone libraries (Lovejoy et al. 2006). MAST-1B and MAST-2, which were retrieved once each in our libraries, have also been reported mostly from surface waters (Massana et al. 2004, Not et al. 2007). On the other hand, MAST-12 sequences are reported mostly from anoxic environments (Massana et al. 2004), such as shallow sediments (Dawson \& Pace 2002). The presence of MAST-12 sequences in the summer sample could be related to such factors as resuspension of the sediment, intrusion of nepheloid layers or presence of particle based microzones of anoxia. The metazoan sequences retrieved from the same sample included several close matches to polychaetes consistent with sediments infiltrating the sample.

Acantharea and Polycystinea sequences were recovered in all 4 seasons. Microscopic observations have reported that Radiolaria assemblages in Beaufort Sea are dominated by the nasselarids Amphimelissa setosa in surface waters and Ceratocyrtis historicosa in deep waters (Itaki et al. 2003); however, no Nasselarida sequencies were retrieved from our clone libraries. Other radiolarians reported by Itaki et al. (2003) included Actinomma spp., but no sequences for this genus are available in public databases for comparison. The most abundant clone in winter corresponded to a Spumellarida associated with a subgroup of environmental clones known as RAD III (Fig. 7), retrieved from deep sea in Sargasso and Caribbean Sea (Not et al. 2007). Another environmental cluster of Acantharean sequences was present throughout the year (identified in Fig. 7 as ACAN I) and clustered apart from its nearest matches, which were other environmental sequences.

\section{Seasonal succession in the mesopelagic zone}

One objective of this study was to evaluate whether the mesopelagic protist community was subject to seasonal changes. Our DGGE and clone library results suggest that the microbial community at depth is dynamic, with marked changes over the year. Two major communities could be separated according to the DGGE and clone libraries results, 1 grouping the autumn-summer samples and another with the winterspring ones (Fig. $2 \mathrm{~A}, \mathrm{~B}$ ). The eukaryotic microbial community at depth was dominated by heterotrophic dinoflagellates in November 2003, at the end of the summer growing season. In early December this community changed abruptly and Group II marine alveolate sequences dominated the clone library. All of the 
samples for this study were collected from the deep Pacific halocline (Fig. 1). In early December the currents at the base of the Pacific halocline reversed flow, changing from south to northwest, and consequently water from Amundsen Gulf entered into Franklin Bay (Forest et al. 2008). This water mass carrying its own microbial assemblage appears to have abruptly replaced the previous season's community. Benoit et al. (2008) describe the transport process inside Franklin Bay during the same period for Arctic cod. The Arctic cod started to passively accumulate in the bottom waters of Franklin Bay at the beginning of winter, transported by the Pacific halocline water moving along the slope. Similarly, the microbial community changes were consistent with the community being advected in from Amundsen Gulf replacing the fall community and persisting in Franklin Bay over winter and spring. These observations underscore how different water masses have different microbial signatures (Hamilton et al. 2008).

The high recovery rate of sequences belonging to putative parasites (Fig. 3) suggests that parasitism is an important process over winter and spring. As far as is known, Group II marine alveolates in the order Syndiniales (Skovgaard et al. 2005, Groisillier et al. 2006, Harada et al. 2007, Guillou et al. 2008, Skovgaard \& Daugbjerg 2008) are strictly endoparasites, although free-swimming dinospores are responsible for the infection of the host (Coats \& Park 2002, Stentiford \& Shields 2005, Frischer et al. 2006). These dinospores reportedly survive only 4 to $12 \mathrm{~d}$ for Amoebophrya spp. (Coats \& Park 2002). We found that closely related sequences from Cluster 6 and the novel Arctic cluster were especially abundant in the winter libraries and were still common in spring, suggesting a persistent or reoccurring infection (Fig. 3).

Although the communities clustered together (Fig. 2B), the diversity was higher in spring compared to winter and with greater evenness (Table 2). Group II marine alveolates remained the dominant group, but other protists, mostly stramenopiles (Table 3, Fig. 6), added to the diversity in spring. The spring community transition driven by an increased irradiance is apparent in the upper mixed layer starting in April (Terrado et al. 2008). The higher diversity found in our spring clone library suggests that the community transition was also developing at depth, though the community was still dominated by winter phylotypes.

The community from July 2004 was similar to that found in November 2003. In both cases, dinoflagellate sequences related to Gyrodinium rubrum dominated the clone libraries. G. rubrum is strictly heterotrophic (it does not contain chloroplasts) and feeds on diverse phytoplankton and even ciliates (Hansen \& Calado 1999, Jeong 1999). The high occurrence of this se- quence in summer and autumn may be coupled to a change to a diatom community in the euphotic zone, with the dinoflagellates consuming sedimenting cells. We only found diatom sequences in the summer and autumn libraries. Forest et al. (2008) used moored sediment trap data to distinguish 2 different pathways for the flux of particulate organic carbon (POC) in Franklin Bay: an algal source of POC (sedimenting phytoplankton cells) and a detrital source of POC. Both pathways contribute to the carbon flux throughout the year, but in fall and summer the algal pathway was dominant. When the algal pathway dominates the POC flux, it is assumed that this carbon continues to sediment to the benthos. However, dinoflagellate grazing could keep the carbon within the living pelagic food web, preventing part of the sedimenting algal biomasses reaching the sea floor. This process would add additional POC processing steps via the microbial food web in deeper waters, resulting in increased respiration and energy losses. Similarly, the persistent parasitic infections of a variety of deep living protists and other eukaryotes over winter could affect carbon transfer to higher trophic levels by shunting biological carbon into the smaller dinospores of parasites.

\section{CONCLUSIONS}

The Arctic coastal mesopelagic zone contains a diverse protist community dominated by alveolates. Sequences in winter and spring corresponded mostly to likely parasites belonging to the uncultured Group II marine alveolates, while in summer and autumn the most abundant sequences were related to the predatory dinoflagellate Gyrodinium rubrum. An abrupt community change from autumn to winter was likely to be related to an influx of Pacific halocline water from Amundsen Gulf entering into Franklin Bay at the beginning of December. The mesopelagic microbial community composition in autumn and summer was consistent with a coupling to primary production in the overlying euphotic zone. In summary, we found that protist communities from this mesopelagic zone were diverse and dynamically coupled to biological and physical oceanographic processes. The return to the same functional and taxonomic community in summer as that from the previous autumn suggests that these deep-living communities may experience an annual pattern of seasonal succession.

Acknowledgements. Financial support for this study was provided by the Natural Sciences and Engineering Research Council of Canada (NSERC), the Canada Research Chair program, Fonds Québécois de rechereche sur la Nature et les 
Technologies and Indian Northern Affairs Canada. We also gratefully acknowledge other team members who collected the DNA samples: F. Unrein, M. Bayer, O. Guadayol, C. Pedrós-Alió, D. Vaque, M. Estrada, L. Alonso and J. Felipe. We thank the officers and crew of the CCGS 'Amundsen' for their efficient work. We also thank 3 anonymous reviewers for suggestions and comments that greatly improved our original submission. This work was conducted within the Canadian Arctic Shelf Exchange Study (CASES).

\section{LITERATURE CITED}

Adl SM, Simpson AGB, Farmer MA, Andersen RA and others (2005) The new higher level classification of eukaryotes with emphasis on the taxonomy of protists. J Eukaryot Microbiol 52:399-451

Altschul SF, Gish W, Miller W, Myers EW, Lipman DJ (1990) Basic local alignment search tool. J Mol Biol 215:403-410

> Anderson CR, Siegel DA, Brzezinski MA, Guillocheau N (2008) Controls on temporal patterns in phytoplankton community structure in the Santa Barbara channel, California. J Geophys Res 113, C04038, doi: 10.1029/ 2007JC004321

Behnke A, Bunge J, Barger K, Breiner HW, Alla V, Stoeck T (2006) Microeukaryote community patterns along an $\mathrm{O}_{2} / \mathrm{H}_{2} \mathrm{~S}$ gradient in a supersulfidic anoxic fjord (Framvaren, Norway). Appl Environ Microbiol 72:3626-3636

> Benoit D, Simard Y, Fortier L (2008) Hydroacoustic detection of large winter aggregations of Arctic cod (Boreogadus saida) at depth in ice-covered Franklin Bay (Beaufort Sea). J Geophys Res 113, C06S90, doi: 10.1029/2007JC004276

Biddanda B, Benner R (1997) Major contribution from mesopelagic plankton to heterotrophic metabolism in the upper ocean. Deep-Sea Res I 44:2069-2085

> Carmack EC, Macdonald RW, Jasper S (2004) Phytoplankton productivity on the Canadian Shelf of the Beaufort Sea. Mar Ecol Prog Ser 277:37-50

Cavalieri DJ, Gloersen P, Parkinson CL, Comiso JC, Zwally HJ (1997) Observed hemispheric asymmetry in global sea ice changes. Science 278:1104-1106

Coats DW (1999) Parasitic life styles of marine dinoflagellates. J Eukaryot Microbiol 46:402-409

Coats DW, Park MG (2002) Parasitism of photosynthetic dinoflagellates by three strains of Amoebophrya (Dinophyta): parasite survival, infectivity, generation time and host specificity. J Phycol 38:520-528

Countway PD, Gast RJ, Dennett MR, Savai P, Rose JM, Caron DA (2007) Distinct protistan assemblages characterize the euphotic zone and deep sea $(2500 \mathrm{~m})$ of the western North Atlantic (Sargasso Sea and Gulf Stream). Environ Microbiol 9:1219-1232

> Dawson SC, Pace NR (2002) Novel kingdom-level eukaryotic diversity in anoxic environments. Proc Natl Acad Sci USA 99:8324-8329

DeLong EF, Franks DG, Aldredge AL (1993) Phylogenetic diversity of aggregate-attached vs. free-living marine bacterial assemblage. Limnol Oceanogr 38:924-934

> Dolven JK, Lindqvist C, Albert VA, Björklund KR, Yuasa T, Takahashi O, Mayama S (2007) Molecular diversity of Alveolates associated with neritic North Atlantic radiolarians. Protist 158:65-76

Edgcomb VP, Kysela DT, Teske A, de Vera Gomez A, Sogin ML (2002) Benthic eukaryotic diversity in the Guaymas Basin hydrothermal vent environment. Proc Natl Acad Sci USA 99:7658-7662
Felsenstein J (2005) PHYLIP — Phylogeny inference package (Version 3.2). Cladistics 5:164-166

Finlay BJ (2004) Protist taxonomy: an ecological perspective. Philos Trans R Soc Lond, B 359:599-610

Finlay BJ, Esteban GF, Brown S, Fenchel T, Hoef-Emden K (2006) Multiple cosmopolitan ecotypes within a microbial eukaryote morphospecies. Protist 157:377-390

Fofonoff NP, Millard RC (1983) Algorithms for computation of fundamental properties of seawater, vol 44. UNESCO Division of Marine Science, Paris

> Forest A, Sampei M, Makabe R, Sasaki H and others (2008) The annual cycle of particulate organic carbon export in Franklin Bay (Canadian Arctic): Environmental control and food web implications. J Geophys Res 113, C03S05, doi: 10.1029/2007JC004262

- Frischer ME, Lee RF, Sheppard MA, Mauer A and others (2006) Evidence for a free-living life stage of the blue crab parasitic dinoflagelate Hematodinium sp. Harmful Algae 5:548-557

Good IJ (1953) The population frequencies of species and the estimation of the population parameters. Biometrika 40:237-264

> Gowing MM, Garrison DL, Wishner KF, Gelfman C (2003) Mesopelagic microplankton of the Arabian Sea. Deep-Sea Res I 50:1205-1234

Greene CH, Pershing AJ (2007) Climate drives sea change. Science 315:1084-1085

Groisillier A, Massana R, Valentin K, Vaulot D, Guillou L (2006) Genetic diversity and habitats of two enigmatic marine alveolate lineages. Aquat Microb Ecol 42:277-291

Guillou L, Viprey M, Chambouvet A, Welsh RM and others (2008) Widespread occurrence and genetic diversity of marine parasitoids belonging to Syndiniales (Alveolata). Environ Microbiol 10:3349-3365

Hamilton AK, Lovejoy C, Galand PE, Ingram RG (2008) Water masses and biogeography of picoeukaryote assemblages in a cold hydrographically complex system. Limnol Oceanogr 53:922-935

Hammer Ø, Harper DAT, Ryan PD (2001) PAST: Paleontological statistics software package for education and data analysis. Palaeontol Electronica 4:9

Hansen PJ, Calado AJ (1999) Phagotrophic mechanisms and prey selection in free-living dinoflagellates. J Eukaryot Microbiol 46:382-389

> Harada A, Ohtsuka S, Horiguchi T (2007) Species of the parasitic genus Duboscquella are members of the enigmatic Marine Alveolate Group I. Protist 158:337-347

> Itaki T, Ito M, Narita H, Ahagon N, Sakai H (2003) Depth distribution of radiolarians from the Chukchi and Beaufort Seas, western Arctic. Deep-Sea Res I 50:1507-1522

Jeong HJ (1999) The ecological roles of heterotrophic dinoflagellates in marine planktonic communities. J Eukaryot Microbiol 46:390-396

Johannessen OM, Shalina EV, Miles MW (1999) Satellite evidence for an Arctic sea ice cover in transformation. Science 286:1937-1939

> Johnson ZI, Zinser ER, Coe A, McNulty NP, Woodward EMS, Chisholm SW (2006) Niche partitioning among Prochlorococcus ecotypes along ocean-scale environmental gradients. Science 311:1737-1740

Larsen A, Flaten GAF, Sandaa RA, Castberg T and others (2004) Spring phytoplankton bloom dynamics in Norwegian coastal waters: Microbial community succession and diversity. Limnol Oceanogr 49:180-190

Litchman E, Klausmeier CA, Miller JR, Schofield OM, Falkowski PG (2006) Multi-nutrient, multi-group model of present and future oceanic phytoplankton communities. 
Biogeosciences 3:585-606

Logares R, Shalchian-Tabrizi K, Boltovskoy A, Rengefors K (2007) Extensive dinoflagellate phylogenies indicate infrequent marine-freshwater transitions. Mol Phylogenet Evol 45:887-903

Lopez-Garcia P, Rodriguez-Valera F, Pedros-Alio C, Moreira D (2001) Unexpected diversity of small eukaryotes in deep-sea Antarctic plankton. Nature 409:603-607

Lovejoy C, Price NM, Legendre L (2004) Role of nutrient supply and loss in controling protist species dominance and microbial food-webs during spring blooms. Aquat Microb Ecol 34:79-92

Lovejoy C, Massana R, Pedrós-Alió C (2006) Diversity and distribution of marine microbial eukaryotes in the Arctic Ocean and adjacent seas. Appl Environ Microbiol 72: 3085-3095

Martiny JBH, Bohannan BJM, Brown JH, Colwell RK and others (2006) Microbial biogeography: putting microorganisms on the map. Nat Rev Microbiol 4:102-112

Massana R, Castresana J, Balagué V, Guillou L and others (2004) Phylogenetic and ecological analysis of novel marine stramenopiles. Appl Environ Microbiol 70: 3528-3534

Massana R, Terrado R, Forn I, Lovejoy C, Pedros-Alio C (2006) Distribution and abundance of uncultured heterotrophic flagellates in the world oceans. Environ Microbiol 8: 1515-1522

Medlin L, Elwood HJ, Stickel S, Sogin ML (1988) The characterization of enzymatically amplified eukaryotic 16S-like rRNA-coding regions. Gene 71:491-499

Medlin LK, Metfies K, Mehl H, Wiltshire K, Valentin K (2006) Picoeukaryotic plankton diversity at the Helgoland time series site as assessed by three molecular methods. Microb Ecol 52:53-71

Michel C, Gosselin M, Nozais C (2002) Preferential sinking export of biogenic silica during the spring and summer in the North Water Polynya (northern Baffin Bay): Temperature or biological control? J Geophys Res 107(C7), 3064, doi: 10.1029/2000JC000408

> Murray AE, Preston CM, Massana R, Taylor LT, Blakis A, Wu K, DeLong EF (1998) Seasonal and spatial variability of bacterial and archaeal assemblages in the coastal waters near Anvers Island, Antarctica. Appl Environ Microbiol 64:2585-2595

Not F, Gausling R, Azam F, Heidelberg JF, Worden AZ (2007) Vertical distribution of picoeukaryotic diversity in the Sargasso Sea. Environ Microbiol 9:1233-1252

Pedrós-Alió C (2006) Marine microbial diversity: can it be determined? Trends Microbiol 14:257-263

Potvin M, Lovejoy C (2009) PCR-based diversity estimates of artificial and environmental 18S rRNA gene libraries. J Eukaryot Microbiol 56:174-181

Richards TA, Vepritskiy AA, Gouliamova DE, NierzwickiBauer SA (2005) The molecular diversity of freshwater picoeukaryotes from an oligotrophic lake reveals diverse, distinctive and globally dispersed lineages. Environ Microbiol 7:1413-1425

Romari K, Vaulot D (2004) Composition and temporal variability of picoeukaryote communities at a coastal site of the English Channel from 18S rDNA sequences. Limnol Oceanogr 49:784-798

Rudels B, Jones EP, Erson LG, Kattner G (1994) On the intermediate waters of the Arctic ocean. AGU Geophysical Monograph 85:33-46

Sakshaug E (2004) Primary and secondary production in Arctic seas. In: Stein R, Macdonald RW (eds) The organic carbon cycle in the Arctic Ocean. Springer-Verlag, Berlin, p $57-81$
Saldarriaga JF, Taylor FJR, Keeling PJ, Cavalier-Smith T (2001) Dinoflagellate nuclear SSU rRNA phylogeny suggests multiple plastid losses and replacements. J Mol Evol 53:204-213

- Schloss PD, Handelsman J (2005) Introducing DOTUR, a computer program for defining operational taxonomic units and estimating species richness. Appl Environ Microbiol 71:1501-1506

Serreze MC, Walsh JE, Chapin FS III, Osterkamp T and others (2000) Observational evidence of recent change in the northern high-latitude environment. Clim Change 46:159-207

Sherr EB, Sherr BF, Wheeler PA, Thompson K (2003) Temporal and spatial variation in stocks of autotrophic and heterotrophic microbes in the upper water column of the central Arctic Ocean. Deep-Sea Res I 50:557-571

Simon M, Rosenstock B, Zwisler W (2004) Coupling of epipelagic and mesopelagic heterotrophic picoplankton production to phytoplankton biomass in the Antarctic polar front region. Limnol Oceanogr 49:1035-1043

Skovgaard A, Daugbjerg N (2008) Identity and systematic position of Paradinium poucheti and other Paradiniumlike parasites of marine copepods based on morphology and nuclear-encoded SSU rDNA. Protist 159:401-413

Skovgaard A, Massana R, Balaguè V, Saiz E (2005) Phylogenetic position of the copepod-infesting parasite Syndinium turbo (Dinoflagellata, Syndinea). Protist 156:413-423

Stentiford GD, Shields JD (2005) A review of the parasitic dinoflagellates Hematodinium species and Hematodinium-like infections in marine crustaceans. Dis Aquat Org $66: 47-70$

> Stoeck T, Taylor GT, Epstein SS (2003) Novel eukaryotes from the permanently anoxic Cariaco Basin (Caribbean Sea). Appl Environ Microbiol 69:5656-5663

Takano Y, Horiguchi T (2004) Surface ultrastructure and molecular phylogenetics of four unarmored heterotrophic dinoflagellates, including the type species of the genus Gyrodinium (Dinophyceae). Phycol Res 52:107-116

Talavera G, Castresana J (2007) Improvement of phylogenies after removing divergent and ambiguously aligned blocks from protein sequence alignments. Syst Biol 56:564-577

Tanaka T, Rassoulzadegan F (2004) Vertical and seasonal variations of bacterial abundance and production in the mesopelagic layer of the NW Mediterranean Sea: bottomup and top-down controls. Deep-Sea Res I 51:531-544

Terrado R, Lovejoy C, Massana R, Vincent WF (2008) Microbial food web responses to light and nutrients beneath arctic sea ice during the winter-spring transition. J Mar Syst 74:964-977

Thompson JD, Gibson TJ, Plewniak F, Jeanmougin F, Higgins DG (1997) The ClustalX windows interface: flexible strategies for multiple sequence alignment aided by quality analysis tools. Nucleic Acids Res 25:4876-4882

> Vaulot D, Eikrem W, Viprey M, Moreau H (2008) The diversity of small eukaryotic phytoplankton $(<3 \mu \mathrm{m})$ in marine ecosystems. FEMS Microbiol Rev 32:795-820

> Webb EA, Ehrenreich IM, Brown SL, Valois FW, Waterbury JB (2009) Phenotypic and genotypic characterization of multiple strains of the diazotrophic cyanobacterium, Crocosphaera watsonii, isolated from the open ocean. Environ Microbiol 11:338-348

Worden AZ (2006) Picoeukaryote diversity in coastal waters of the Pacific Ocean. Aquat Microb Ecol 43:165-175

Zhu F, Massana R, Not F, Marie D, Vaulot D (2005) Mapping of picoeukaryotes in marine ecosystems with quantitative PCR of the 18S rRNA gene. FEMS Microbiol Ecol 52: $79-92$

Submitted: September 2, 2008; Accepted: May 6, 2009

Proofs received from author(s): July 6, 2009 